\title{
MODELE ZARZĄDZANIA INFORMACJA W SERWISACH WWW KRAKOWSKICH BIBLIOTEK AKADEMICKICH
}

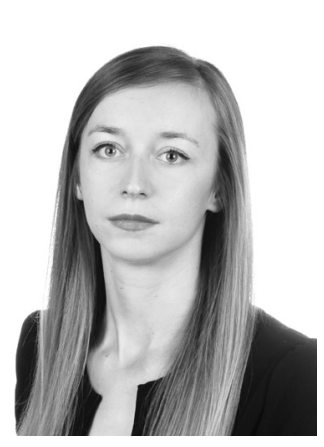

\begin{abstract}
Absolwentka studiów magisterskich na kierunku informacja naukowa i bibliotekoznawstwo w Instytucie Informacji Naukowej i Bibliotekoznawstwa Uniwersytetu Jagiellońskiego. Doktorantka Wydziału Zarządzania i Komunikacji Społecznej UJ. Jej zainteresowania badawcze skupione są wokół problematyki zachowań informacyjnych, ze szczególnym uwzględnieniem indywidualnego zarządzania informacja, a dodatkowo wokół użytkowników bibliotek akademickich.
\end{abstract}

SŁOWA KLUCZOWE: Biblioteki akademickie. Serwisy WWW. Multi Case Study.

ABSTRAKT: Teza/cel artykułu: Celem artykułu jest rozpoznanie modeli zarządzania informacją realizowanych w praktyce zarządzania serwisami WWW bibliotek akademickich. Metody badań: Jako metoda badawcza zastosowane zostało podejście multi-case study. Przeanalizowane zostały procesy zarządzania informacją w serwisach WWW pięciu różnych bibliotek akademickich. Zastosowany został częściowo ustrukturyzowany wywiad z dążeniem do jego pogłębienia. Wyniki i wnioski: Zidentyfikowane zostały dwa dominujące modele zarządzania informacją. Pierwszy - widoczny w mniejszych bibliotekach, w który zaangażowany jest jeden lub dwóch redaktorów, a procesy zarządzania przebiegają szybko, są jednak obarczone ryzykiem błędu. Drugi - widoczny w większych placówkach, gdzie nad serwisem WWW czuwa cały zespół redakcyjny, kontrola treści jest na wyższym poziomie, jednak proces zarządzania jest długotrwały. 


\section{WPROWADZENIE}

Zarządzanie informacją to jeden z ważniejszych kierunków dociekań we współczesnej nauce o informacji. Ten szeroko rozumiany, kompleksowy proces realizowany jest przez każdą instytucję, a jego przebieg w bibliotekach jest rozpatrywany z punktu widzenia bibliologii i informatologii. Jako utrwalony i upubliczniony wynik procesu zarządzania informacją przyjęłam zawartość bibliotecznych serwisów WWW, zatem celem artykułu jest rozpoznanie modeli zarządzania informacją realizowanych w praktyce zarządzania serwisami WWW bibliotek akademickich. Przyjęłam perspektywę badań jakościowych, zatem celem nie jest wykrycie wszystkich istniejących, lecz heurystyczna próba wykrycia niektórych możliwych modeli.

Serwis WWW biblioteki (w artykule z przyczyn stylistycznych termin ten stosowany jest zamiennie $\mathrm{z}$ terminem portal biblioteczny), rozumiem jako zespół powiązanych stron internetowych, zarządzanych lub prowadzonych przez jedną bibliotekę lub inną instytucję z jej upoważnienia, cechujący się jednolitą identyfikacją wizualną i funkcjonalną. Oprócz stron internetowych serwis może zawierać także dokumenty udostępniane w Internecie, a dostęp możliwy jest przy użyciu jednego adresu domenowego (SJP PWN).

Remigiusz Sapa do najważniejszych funkcji bibliotecznych serwisów WWW zalicza:

„1. dostarczanie informacji online o zasobach tradycyjnych bibliotek i obsługa procesów związanych z ich udostępnianiem (...),

2. pośredniczenie $\mathrm{w}$ dostępie do zasobów online niezintegrowanych ze środowiskiem WWW,

3. organizacja dostępu do zasobów WWW i informacji online zintegrowanej ze środowiskiem WWW,

4. realizacja usług informacyjnych online,

5. kształcenie użytkownika informacji,

6. organizacja przestrzeni komunikacji dla użytkowników biblioteki,

7. promowanie serwisu i biblioteki oraz zadania z zakresu public relations,

8. dostarczanie informacji dla kooperantów i obsługa współpracy (...)." (Sapa, 2004).

\section{SERWISY WWW BIBLIOTEK AKADEMICKICH}

Anglojęzyczne piśmiennictwo dotyczące serwisów WWW bibliotek akademickich jest dosyć bogate, jednak nie znalazłam publikacji poruszających bezpośrednio problematykę modeli zarządzania informacją $\mathrm{w}$ nich widocznych. Przy okazji badań nad serwisami WWW bibliotek akademickich kilka tematów wyłania się jednak jako najczęściej poruszane. Portale biblioteczne są niekiedy uważane za wirtualne przedłużenie klasycznie rozumianej, fizycznie istniejącej biblioteki. Do sieci przeniesione są wtedy podstawowe jej 
funkcje, umożliwiając użytkownikom korzystanie z niej na odległość (Joo, 2011; Mierzecka \& Suminas, 2016). Popularnym tematem są techniki prowadzenia serwisu. Jeżeli chodzi o platformę publikowania, biblioteki akademickie często decydują się na (lub wyznacza im się) pracę przy użyciu systemu do zarządzania treścią (ang. Content Management System, CMS). Zaletą korzystania z takiego rozwiązania jest zakładany brak konieczności posiadania specjalistycznej wiedzy technicznej przez redaktora. Może on wtedy skupić się na sensownym rozplanowaniu informacji, natomiast sama jej publikacja jest prosta i szybka. Łatwiej jest również modyfikować lub usuwać informację nieaktualna, nadmierną lub nieuporządkowaną (Black, 2011). Warto zauważyć, że uwaga badaczy skierowana jest też na osoby prowadzące serwisy WWW. Nawet korzystając z gotowego szablonu czy systemu ułatwiającego tworzenie portalu, powinni starać się go rozwijać, co możliwe jest dzięki rozwijaniu umiejętności w zakresie stosowania technologii informacyjnych. Opisane zostały różne metody ewaluacji serwisów WWW, pozwalające je ocenić, a w efekcie - lepiej planować i doskonalić (Popp, 2001). Przy zastosowaniu badań ankietowych badano też trendy w wyborze konkretnych CMS-ów przez biblioteki akademickie (Connel, 2013).

Często poruszana jest tematyka użytkowników bibliotek. Serwis WWW traktowany jest jako przewodnik i sposób na komunikowanie się biblioteki z użytkownikami (Nooshinfard, 2011). Ma przyciągać uwagę, interesować i informować. Z kolei skuteczne wykorzystywanie tego kanału nie jest możliwe bez jednoczesnego badania potrzeb i oczekiwań użytkowników. Do komunikacji z nimi, oprócz serwisu, używa się także wciąż popularnych narzędzi Web 2.0, a w szczególności takich serwisów społecznościowych, jak Facebook czy Twitter, które pozwalają na dwukierunkową komunikację, co jest doskonałym uzupełnieniem działania serwisu WWW. Zwłaszcza, że korzystając z CMS, w łatwy sposób można umieścić widget pozwalający na połączenie się z którymś z serwisów społecznościowych na portalu bibliotecznym, z czego biblioteki chętnie korzystają (Wakimoto, 2014).

Generalnie rzecz ujmując, badania dotyczące serwisów WWW bibliotek akademickich wykazały, że serwisy pomagają zarówno bibliotekarzom, jak i użytkownikom w zarządzaniu informacją a głównymi celami ich prowadzenia są: promocja, prezentowanie informacji o zasobach, dostęp do katalogów i baz, publikacja ogłoszeń, udostępnianie użytkownikom zasobów wiarygodnych lub samodzielnie przygotowanych, na przykład tutoriali.

\section{ZARZĄDZANIE INFORMACJA}

Pojęcie „zarządzanie informacją", rozpowszechnione obecnie szeroko w dziedzinie nauki o informacji, wywodzi się z nauk o zarządzaniu.

$\mathrm{W}$ polskim piśmiennictwie z zakresu bibliologii i informatologii tematyką zarządzania informacją zajmują się m.in. Marzena Świgoń, 
Katarzyna Materska, Wanda Krystyna Roman. Zarządzanie informacją może być generalnie definiowane jako najczęściej świadome postępowanie ludzi, zmierzające $\mathrm{w}$ kierunku optymalizacji roli informacji w osiąganiu celów przez organizację (Roman, 2012). M. Świgoń pisząc o zarządzaniu informacją zwraca uwagę na takie jego komponenty, jak: gromadzenie, organizowanie, dzielenie się i tworzenie nowej informacji i wiedzy. Podkreśla ponadto jego interdyscyplinarność, jak również bogaty wkład specjalistów z zakresu informacji naukowej w rozwój tego pola badawczego (Świgoń, 2016). K. Materska uznaje zarządzanie informacją i wiedzą w nauce za "planowy, zintegrowany i systematyczny zestaw działań, którego celem jest odpowiednie kształtowanie zasobów oraz przepływów informacji i wiedzy (kreowania warunków) w obszarze nauki (w instytucjach, także wirtualnych, w sieciach), zgodnie z potrzebami i celami tego środowiska" (Materska, 2012).

Podobne podejście do kwestii zarządzania informacją widoczne jest w piśmiennictwie zagranicznym. Jak podaje ODLIS, zarządzanie informacją to „umiejętne sprawowanie kontroli nad nabywaniem, porządkowaniem, przechowywaniem, ochroną, jak i rozpowszechnianie zasobów informacyjnych niezbędnych dla prawidłowego funkcjonowania przedsiębiorstw, organizacji i instytucji, łącznie z tworzeniem dokumentacji, zarządzaniem rekordami i infrastrukturą techniczną" (tłum. własne) (ODLIS, 2016). Chun Wei Choo traktuje zarządzanie informacją nieco inaczej - jako szereg procesów ściśle powiązanych z uczeniem się organizacji. Według niego umożliwianie adaptowania się organizacji do jej zmieniającego się otoczenia za pomocą posiadanych zasobów informacyjnych (i informatycznych) jest podstawowym celem zarządzania informacją (Chun Wei Choo, 1995). Jak podkreślają Elena Macevičiūtė i Thomas D. Wilson, można zauważyć, że zarządzanie informacją to pojęcie bardzo złożone. Nie chodzi tu wyłącznie o trudność, a według niektórych badaczy nawet niemożność zdefiniowania informacji (Wojciechowski, 2000), lecz także o to, jak rozłożone zostaną akcenty, jaka perspektywa badawcza zostanie przyjęta oraz jaki kontekst towarzyszy użyciu pojęcia (Macevičiūtė \& Wilson, 2002).

Nie ulega jednak wątpliwości, że ta dynamicznie rozwijająca się dziedzina to nie tylko rozważania teoretyczne, ale też szeroki zakres działań profesjonalnych. Zarządzanie informacją przez bibliotekę obejmuje zatem wszelkie czynności, podejmowane przez jej pracowników, które mają na celu komunikację wewnętrzną, jak i zewnętrzną biblioteki tak, aby każda osoba z nią powiązana, zarówno pracownicy, jak i użytkownicy (również potencjalni), mieli możliwość skutecznego dotarcia do informacji na jej temat lub wytworzonych przez nią. Jest to zatem proces, który jest trwały i postępujący w czasie. 


\section{FUNKCJE ZARZĄDZANIA INFORMACJĄ}

W swojej istocie proces zarządzania, również informacją jest złożony i da się wyróżnić w nim poszczególne etapy: planowanie, organizowanie, kierowanie i kontrola (np. Czekaj, 2000; Griffin, 2004; Wrycza, 2010). Planowanie rozumiane jest jako refleksja nad zadaniami, koniecznymi do podjęcia, $\mathrm{w}$ celu osiagnięcia zakładanych rezultatów, kształtowanie działań oraz ich koordynacja. Najistotniejszy zatem jest przedmiot (co jest planowane), czas (kiedy to ma zostać wykonane) oraz ludzie (i dla kogo). Organizowanie dotyczy kolejnego etapu, czyli tworzenia podziału pracy. Mieści się tutaj zarówno podział zadania na mniejsze elementy, lecz także wychwycenie powiązań między nimi. Budowanie systemu komunikacji pomiędzy poszczególnymi podmiotami, wykonującymi zadania w zakresie zarządzania również znajduje się w zakresie organizowania. Kontrolowanie to rejestracja i ewaluacja osiąganych wyników. Dokonywana jest nie tylko przez poszczególne organy, które w zakresie swoich działań mają kontrolowanie, na przykład kierownictwo, lecz spotkać się można również z samokontrolą pracowników po wykonaniu pewnego zadania. Oczywiście sposoby realizowania poszczególnych funkcji zarządzania w konkretnej organizacji zależą od jej indywidualnych cech: wielkości, struktury, kultury organizacyjnej itd.

Niektórzy badacze, m.in. W. K. Roman i J. Czekaj twierdza, że zarządzanie informacja, jako proces celowy i systematyczny, powinno być przeprowadzane zgodnie z klasycznymi elementami zarządzania, co stało się podstawowym założeniem przeprowadzonego przeze mnie badania. W tym kontekście istotną rolę pełni zestawienie przytoczonych powyżej wzorcowych elementów zarządzania z faktycznymi procesami, które dokonują się podczas zarządzania informacją przez biblioteki akademickie w serwisach WWW. Jako przykład takich procesów może posłużyć publikowanie aktualności w serwisie lub archiwizowanie informacji po jej usunięciu z widocznej dla użytkowników części witryny.

\section{PROJEKT I PRZEBIEG BADANIA}

Jako metodologia badawcza zastosowane zostało podejście multi-case study. Przeanalizowane zostały procesy zarządzania informacją $w$ serwisach WWW pięciu bibliotek akademickich. Opis modeli zarządzania w tych bibliotekach możliwy jest dzięki jakościowemu podejściu, zrealizowanemu w pogłębionych wywiadach, przeprowadzonych z osobami odpowiedzialnymi za zamieszczanie treści w serwisach bibliotek akademickich. Zastosowany został częściowo ustrukturyzowany wywiad. Standardowe pytania zadawane były każdemu z respondentów, aby osiągnąć dające się porównywać odpowiedzi. Wywiady rekomendowane są do badania jednostek, w tym przypadku wyselekcjonowanych placówek bibliotecznych, lecz dają 
się w ten sposób również badać zjawiska typowe, zatem możliwe jest interpretowanie wyników w celu nakreślenia pewnych modeli, o ile takie wyłaniają się z badania (Wojciechowski, 2000).

Kwestionariusz składał się z 12 pytań otwartych (zob. aneks). Pytania sformułowane zostały w sposób, który oddawał zarówno strukturę, jak i kolejność występowania poszczególnych, klasycznie rozumianych elementów zarządzania, o których wspomniałam wcześniej. Pytania dotyczyły zatem podejmowania decyzji na temat planowania, organizowania, kierowania i kontrolowania procesów związanych z zarządzaniem informacją w konkretnej bibliotece. Pytałam także o istnienie oficjalnych dokumentów, które determinują układ i wygląd publikowanych informacji, a także o sposoby podejmowania najważniejszych działań, dotyczących publikowania treści.

Badanie przeprowadzono w okresie luty 2015 - styczeń 2016 r. Dobór instytucji do badania był celowy i wynikał z chęci zidentyfikowania modeli zarządzania informacją w placówkach o różnych profilach zbiorów i użytkowników. Wspólną cechą wszystkich bibliotek objętych badaniem był status biblioteki akademickiej oraz posiadanie serwisu WWW. Badania przeprowadziłam w następujących instytucjach: Biblioteka Jagiellońska, Biblioteka Politechniki Krakowskiej, Biblioteka Akademii Sztuk Pięknych w Krakowie, Biblioteka Główna Uniwersytetu Ekonomicznego w Krakowie oraz Biblioteka Krakowskiej Akademii im. Andrzeja Frycza Modrzewskiego. Wywiady trwały od 30 do 90 minut, w trzech przypadkach wywiad przeprowadzano z jednym rozmówca, a w dwóch pozostałych - z dwoma.

\section{PROCESY ZARZĄDZANIA INFORMACJĄ W PRAKTYCE PROWADZENIA SERWISÓW WWW}

Przebieg planowania, organizowania, kierowania i kontroli treści bibliotecznych serwisów WWW wynika z wielu różnych uwarunkowań każdej $z$ badanych instytucji. Szczegółowe przyjrzenie się każdemu z nich pozwala na wyłonienie podobieństw i nakreślenie głównych modeli zarządzania w ujęciu całościowym.

Biorąc pod uwagę planowanie w zakresie publikowania treści na portalu biblioteki, $\mathrm{w}$ żadnej z badanych bibliotek nie wypracowano dokumentów, które określałyby tryb lub sposób tych działań. Dwóch respondentów powołało się na istniejące księgi identyfikacji wizualnej, czyli wytyczne dotyczące na przykład prezentowania logo lub korzystania z kolorystyki uczelni, obowiązujące w całej instytucji. Brak jednak dokumentów odnoszących się wyłącznie do sposobu budowania i prowadzenia serwisu WWW biblioteki. Jako przykłady działań w zakresie planowania struktury i treści, respondenci wymieniają:

- spotkania zespołowe (cykliczne lub spontaniczne);

- burze mózgów; 
- prośby o zgłaszanie swoich propozycji, kierowane do osób spoza działu;

- opieranie się na swoim doświadczeniu i intuicji;

- zarządzenia kierownictwa i dyrekcji.

Często jednak planowanie ma charakter spontaniczny, czyli stanowi reakcję na aktualne potrzeby lub wydarzenia biblioteczne albo dotyczące całej uczelni. Pokazuje to wypowiedź jednego z respondentów: „Zdarza się, że użytkownicy sami wychodzą z inicjatywa, pisza, dzwonia, następuje wymiana informacji. Informatycy również podpowiadaja, co zmieniać, by było ergonomicznie od strony technicznej, na przykład jeśli chodzi o dostosowanie strony do urządzeń mobilnych lub użytkowników niedowidzących".

Organizowanie zaplanowanych działań to kolejna funkcja zarządzania informacją w serwisie WWW biblioteki. Decyzje w tym zakresie w badanych bibliotekach podejmuje albo jedna osoba, albo cały zespół, na przykład pracownicy oddziału informacji naukowej lub zespół redakcyjny, zajmujący się aktualizowaniem portalu. W zależności od tego, czy biblioteka dysponuje autonomicznym serwisem WWW, czy też jest on częścią portalu uczelni, osoby zarządzające informacją mają większy bądź mniejszy wpływ na wygląd witryny. Najczęściej serwisy oparte są na szablonach, w skład których wchodzą gotowe moduły, a możliwości ich modyfikacji są ograniczone. Cytat z wypowiedzi jednego z respondentów może to zilustrować: „Mamy wpływ na układ logiczny tych treści, (...) natomiast są pewne stałe elementy, czyli ta górna część, których nie możemy zmienić. To co jest poniżej, to już wszystko właściwie możemy sobie personalizować, (...) nie jesteśmy zobligowani do jakiegoś konkretnego układu tej treści i możemy układać, jeśli chodzi o układ, po swojemu".

Wszyscy respondenci podkreślali, że w organizowaniu treści największą wagę przykładają do tego, by odpowiadać potrzebom biblioteki oraz potrzebom jej użytkowników. „Z punktu widzenia użytkownika wprowadzanie informacji w dwóch miejscach było mylące. Jesteśmy pomocą też jeśli chodzi o korzystanie ze strony uczelni i znajdowanie tej informacji bo czasem trudno tam znaleźć informacje”. W innej z badanych bibliotek: „zmiany przebiegają wtedy, gdy strona przestaje odpowiadać potrzebom użytkowników". Przeprowadzane są próby badania użytkowników, jak powiedział jeden z rozmówców: „Przez aplikację Google śledzona jest ilość wejść, klikanie w linki, jednak na razie nie zdążyliśmy wykorzystać wyników tych analiz".

Ponadto duży nacisk kładziony jest na współpracę w zespołach zajmujących się redakcją strony - podkreśla się wagę dyskutowania nad bieżącymi potrzebami i podejmowania decyzji na tej podstawie. Proces powstawania tych zespołów nie zawsze jednak jest sformalizowany. Wskazuje na to wypowiedź: „Nie było to objęte żadnymi formalnościami, było to na zasadzie kogo można by do tego zespołu wciągnąć, kto mógłby wnieść coś ciekawego do tego. Tak chyba to wyglądało obiektywnie. Jeśli chodzi o stan obecny no to kto decyduje o planowaniu struktury... no to też jest efekt jakiegoś konsensusu”. Kolejna wypowiedź: „To chyba bardziej jednak jest współpraca na 
niższym poziomie to znaczy że te osoby, które są zaangażowane nieformalnie, no to one jakby się organizują i próbują coś tam w tej treści zmieniać". Występują również bardziej sformalizowane metody pracy nad serwisem WWW w obrębie zespołu: „W każdym oddziale są osoby odpowiedzialne za aktualizację, jest interfejs dla bibliotekarzy, istnieje mechanizm przydzielania uprawnień".

Kierowanie mieści w swoim zakresie te elementy zarządzania, które pomagają $\mathrm{w}$ organizowaniu procesów poprzez ich nadzorowanie, wskazywanie celów i wyjaśnianie zadań. W literaturze często wskazuje się też na związane $\mathrm{z}$ tym motywowanie. $\mathrm{W}$ badanych bibliotekach zadanie to realizuje bądź dyrekcja, bądź osoba kierująca pracami publikacyjnymi. W niektórych przypadkach dyrekcja nie ingeruje $\mathrm{w}$ pracę redaktorów serwisu bibliotecznego, wtedy funkcja ta spoczywa na samodzielnym redaktorze. Ukazuje to na przykład następująca wypowiedź: „Tak, po prostu są takie też aktualności techniczne (na przykład wypożyczenia świąteczne). (...) Wtedy mamy przygotowane szablony, wpisujemy informacje i dajemy grafiki. Albo po prostu nie wrzucamy, jeśli uznamy, że coś się nie nadaje".

Kontrola treści przebiega w badanych bibliotekach już na poziomie decyzji o jej przyjęciu bądź nie. Zazwyczaj informacje publikowane są w tych rubrykach, o które prosi osoba dostarczająca informację. Zdarza się jednak, że osoba publikująca podejmuje decyzję o przesunięciu informacji do innego działu serwisu, na inny kanał komunikacji (na przykład Facebook) lub rezygnacji z publikowania (z rozmaitych powodów). Jeden $\mathrm{z}$ respondentów, na pytanie, jakie treści są odrzucane lub przenoszone, od powiedział następująco: "No rzeczy nie pasujące do struktury. Ktoś chce włożyć coś dziwnego w jakieś miejsce, do którego to zupełnie nie pasuje z naszego punktu widzenia, no i się to wtedy tam nie znajduje. Bywa, że trafia do aktualności, nie trafia np. do zakładki o bibliotece, albo nie znajdzie się na stronie w ogóle i trafi tylko na Facebooka. Zmiany w kluczowych miejscach strony wynikają na przykład ze zmian struktury uczelni, na przykład zakładka zasoby cyfrowe i linki jest ułożona w podziale jak wydziały uczelni. Gdy nastąpiła zmiana struktury uczelni, no to te zmiany musiały mieć w tym miejscu swoje odzwierciedlenie".

Zdarza się, że osoby odpowiedzialne za publikację proszą swoich współpracowników o kontrolę zawartości serwisu, na przykład pod kątem błędów językowych lub poprawności wyświetlania się grafik. Najczęściej konieczna jest akceptacja planowanych treści przez dyrekcję i kierowników, jednak w dwóch badanych bibliotekach osoby publikujące przyznały, że dyrekcja darzy je pełnym zaufaniem i nie ma potrzeby przedkładania planów do akceptacji. Kontrola treści jest niekiedy określana jako okazyjna i spontaniczna. „Jak się zapoznasz ze stroną dogłębnie, to zobaczysz, że tam widać ewidentnie, że nad tymi informacjami nie ma kontroli i nie ma jednego człowieka lub zespołu, który by je jakoś jednolicie przygotował, redagował pod kątem spójności tych treści, żeby miały wspólną formę. Tam są dokumenty o róż- 
nym charakterze...”. W kolejnej z badanych instytucji: „Była osoba, która poprawiała, ale jej styl też odbiegał od dobrego stylu. W tym momencie mamy pełne zaufanie pani dyrektor, jest zadowolona $z$ naszej pracy i nie ingeruje w to jakoś”. W innej bibliotece z kolei „Zdarza się, że ktoś prosi o zmianę interpunkcyjną lub stylistyczną".

Należy także wspomnieć o archiwizowaniu treści, które stają się nieaktualne lub po prostu nie mieszczą się fizycznie w serwisie. W jednej z badanych bibliotek są one archiwizowane od kilku lat $w$ formie jednego dokumentu tekstowego. W innej z kolei, treści cały czas od strony panelu edycyjnego są zapisane w portalu bibliotecznym, jednak wyłączona jest ich widoczność dla użytkowników serwisu. „Te informacje, które znikną ze strony są archiwizowane, wszystko od kilku lat (od 2011). Wtedy zaczęliśmy się brać za to tak na poważnie. Ale to archiwizowane są tylko aktualności i z kilku miejsc jeszcze strony, takie uczelniane rzeczy".

\section{MODELE ZARZĄDZANIA INFORMACJĄ W PORTALACH BIBLIOTEK AKADEMICKICH}

W wyniku badania zidentyfikowane zostały dwa główne, wyłaniające się możliwe modele zarządzania informacją w serwisach WWW bibliotek akademickich.

Pierwszy jest widoczny w dużych bibliotekach. Istnieje zespół (formalny lub nieformalny), zajmujący się podejmowaniem decyzji dotyczących struktury informacji publikowanych przez bibliotekę. Tworzenie takich zespołów często przebiega na zasadzie zdroworozsądkowego podejścia (kto mógłby coś wnieść? Czyja wiedza może się przydać? Kogo warto zapytać o zdanie w danej kwestii?). Formalną pieczę i kontrolę pełni dyrekcja biblioteki, jednak często zespół w swoim gronie podejmuje decyzje i przekłada je dyrekcji do akceptacji. W takiej sytuacji zazwyczaj wskazanych jest kilka osób, którym nadawane są określone uprawnienia do publikowania informacji w konkretnej części serwisu (bez dostępu do innych). Taki model zarządzania może skutkować brakiem jednolitości formy publikowanych treści. Aby tego uniknąć, zespoły ustalają obowiązujące szablony publikowania, których przestrzegania pilnują wzajemnie członkowie zespołów. Wynika z tego zaleta takiego modelu zarządzania informacją, mianowicie kontrola publikowanych treści, często określana jako „spontaniczna”. Zarządzanie informacją w tym modelu przebiega powoli (Rys. 1).

Drugi model zarządzania informacją widoczny jest w bibliotekach, gdzie brak jest osobnego działu lub zespołu zajmującego się stroną internetową. W tych przypadkach decyzje podejmowane są przez 1-2 osoby, które też mają pełną władzę nad tym, co publikują w serwisie. Publikowane treści mają charakter bardziej ujednolicony, kontrola i podejmowanie decyzji nie są rozproszone, przez co procesy mogą przebiegać szybciej (Rys. 2). 


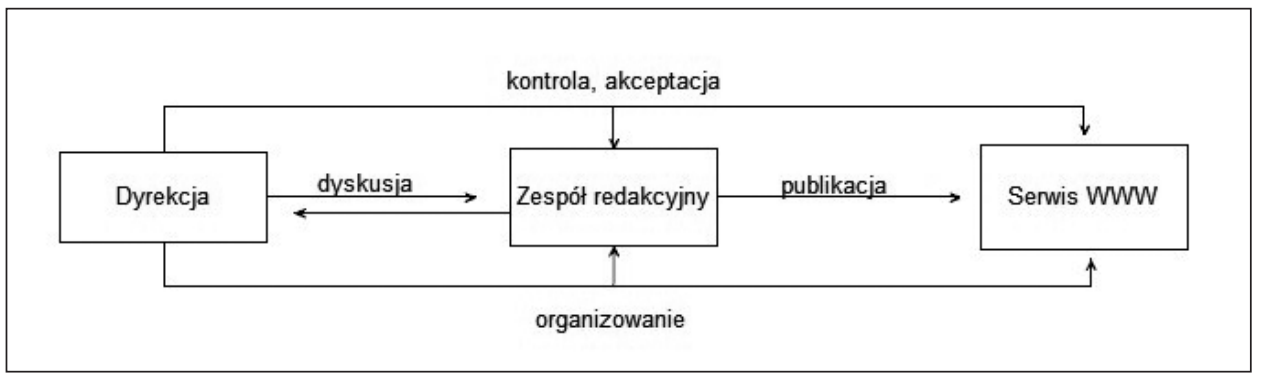

Rys. 1. Model zarządzania informacją w serwisie bibliotecznym tworzonym

Oprac. własne.

$$
\text { przez duży zespół redakcyjny }
$$

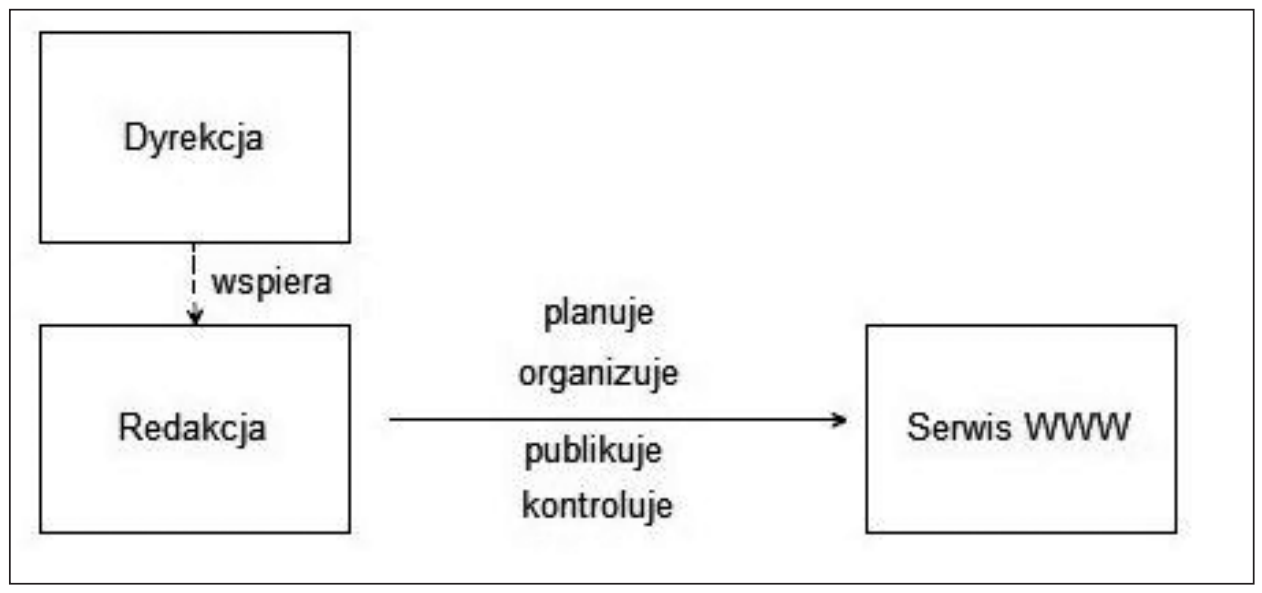

Rys. 2. Model zarządzania informacją w serwisie bibliotecznym tworzonym

przez jedno- lub dwuosobowy zespół redakcyjny

Oprac. własne.

\section{ZAKOŃCZENIE}

W praktyce zarządzania informacją w serwisach WWW bibliotek akademickich największy wpływ na sposób prezentowania treści ma sam redaktor. Zdarza się bowiem, że jedna osoba jest od początku do końca odpowiedzialna za proces publikacji, a więc przechodzi przez wszystkie etapy procesu zarządzania informacją: planuje, organizuje, nadzoruje a także kontroluje publikowane treści często i w nielinearny sposób. Tylko w jednej bibliotece osoba zajmująca się publikowaniem treści na stronie nie ma takiego zapisu w wykazie obowiązków na swoim stanowisku pracy. W żadnej z przebadanych bibliotek nie istnieją oficjalne dokumenty, które określałyby układ lub formę publikowanych treści. Część bibliotek jednak powoływała się na księgi identyfikacji wizualnej (obowiązujące w całej strukturze uczelni), które do pewnego stopnia determinują strukturę publikowanych 
informacji. Kilka bibliotek nie posiada samodzielnego serwisu, lecz ich serwis jest częścią serwisu całej uczelni. W takiej sytuacji bibliotekarze mają niewielki wpływ na układ treści, nadal jednak mogą dokonywać pewnych modyfikacji, ułatwiających użytkownikom dostęp do informacji.

Proces zarządzania informacją $\mathrm{w}$ serwisach WWW bibliotek akademickich jest złożony i bywa chaotyczny. W tym badaniu zidentyfikowano dwa główne modele, jednak temat daje bez wątpienia możliwość dalszych badań i głębszych analiz.

\section{Aneks}

Kwestionariusz wywiadu

1. Czy istnieją dokumenty określające sposób zarządzania informacją w serwisie WWW Państwa biblioteki? Co dokładnie określają?

2. Czy istnieją dokumenty determinujące wygląd i układ zamieszczanych treści? Co dokładnie określają?

3. Czy obowiązki pracowników biblioteki, związane z zarządzaniem informacją w serwisie WWW, mają odzwierciedlenie $\mathrm{w}$ formalnych opisach stanowisk pracy?

4. Kto decyduje o planowaniu struktury i zawartości informacji publikowanych w serwisie WWW biblioteki?

5. W jaki sposób / w jakich sytuacjach / kiedy podejmowane są te decyzje?

6. Kto decyduje o organizowaniu struktury i zawartości informacji publikowanych w serwisie WWW biblioteki?

7. W jaki sposób / w jakich sytuacjach / kiedy podejmowane są te decyzje?

8. Kto kieruje poszczególnymi procesami zarządzania informacją (pozyskiwanie, selekcja, redakcja) w serwisie WWW biblioteki?

9. W jaki sposób / w jakich sytuacjach / kiedy podejmowane są te decyzje?

10. Kto dokonuje kontroli struktury i zawartości informacji publikowanych w serwisie WWW biblioteki?

11. W jaki sposób / w jakich sytuacjach / kiedy podejmowane są te decyzje?

12. W jaki sposób przebiegają rzeczywiste procesy (pozyskiwanie, selekcja, redakcja) bieżącego zarządzania informacją w bibliotecznych serwisach WWW i kto odpowiada za ich realizację?

\section{BIBLIOGRAFIA}

Black, Elizabeth L. (2011). Selecting a Web Content Management System for an Academic Library Website. Information Technology and Libraries, vol 30, no. 4.

Cisek, Sabina (2005). Funkcje i role bibliotek naukowych i publicznych w społeczeństwie wiedzy, [online], [dostęp: 5.01.2017]. Dostępny w WWW: <http://www.academia.edu/6441585/ Funkcje_i_role_bibliotek_naukowych_i_publicznych_w_spo $\%$ C5\%82ecze $\%$ C5\%84stwie_wiedzy>.

Connel, Ruth Sara (2013). Content Management Systems: Trends in Academic Libraries. Information Technology \& Libraries, vol. 32, iss. 2, p. 42. 
Czekaj, Janusz (2000). Metody zarządzania informacją w przedsiębiorstwie, Kraków: Wydaw. Akademii Ekonomicznej.

Griffin, Ricky W. (2004). Podstawy zarzadzania organizacjami. Warszawa: Wydaw. Naukowe PWN.

Information management, w: Online Dictionary for Library and Information Science, [online], [dostęp: 22.02.2017]. Dostępny w WWW: <http://www.abc-clio.com/ODLIS/odlis_i.aspx>.

Materska, Katarzyna (2012). W poszukiwaniu modelu zarzadzania informacja i wiedza w nauce, [online], [dostęp: 5.01.2017]. Dostępny w WWW: <http://www.ptin.org.pl/konferencje/Z2012/repozytorium/Materska.pdf $>$.

Mierzecka, Anna; Suminas, Andrius (2016). Academic library website functions in the context of users' information needs. Journal of Librarianship and Information Science.

Nooshinfard, Fatemeh; Ziaei, Soraya (2011). Academic Library Websites as Marketing Tools, [online]. Library Philosophy \& Practice, p. 64 [dostęp: 5.01.2017]. Dostępny w WWW: <http://digitalcommons.unl.edu/cgi/viewcontent.cgi?article=1631\&context=libphilprac $>$.

Popp, Mary Pagliero (2001). Testing Library Web Sites: ARL Libraries Weigh In. In: Crossing the Divide: Proceedings of the ACRL 10th National Conference, March 15-18, 2001, Denver. Ed. by H. A. Thompson, pp. 277-281.

Roman, Wanda Krystyna (2012). Podstawy zarządzania informacją. Toruń: Wydaw. Naukowe UMK.

Sapa, Remigiusz (2005). Benchmarking w doskonaleniu serwisów WWW bibliotek akademickich. Kraków: Wydaw. UJ.

Słownik Języka Polskiego PWN. W: Serwis internetowy [online], [dostęp 5.01.2017]. Dostępny w WWW: <http://sjp.pwn.pl/sjp/serwis-internetowy;5579204.html>.

Joo, Soohyung; Lin, Suyu; Lu, Kun (2011). A usability evaluation model for academic library websites: efficiency, effectiveness and learnability. Journal of Library and Information Studies, no. 9 (2), pp. 11-26.

Świgoń, Marzena (2009). Personal Knowledge Management - Indywidualne zarządzanie wiedza, [online], [dostęp: 6.01.2017]. Dostępny w WWW: <http://eprints.rclis. org/13854/1/Marzena\%C5\%9Awigo\%C5\%84.Personal_Knowledge_Management.pdf $>$.

Świgoń, Marzena (2012). Zarządzanie wiedza i informacja: podstawy teoretyczne, badania w wymiarze indywidualnym. Olsztyn: Wydaw. UWM.

Wakimoto, Diana. (2014). Academic Library Websites Show Heavy Use of Web 2.0 Applications. Evidence Based Library and Information Practice, no. 9(4), pp. 67-69.

Wojciechowski, Jacek (2000). Czytelnictwo. Kraków: Wydaw. UJ.

Wrycza, Stanisław (2010). Informatyka ekonomiczna. Podręcznik akademicki. Warszawa: Polskie Wydawnictwo Ekonomiczne.

Zygała, Ryszard (2007). Podstawy zarzadzania informacja w przedsiębiorstwie. Wrocław: Wydaw. Akademii Ekonomicznej.

Artykut w wersji poprawionej wptyną do Redakcji 8 sierpnia 2017 r. 
KAROLINA PIAŚNIK-KRAKOWSKA

Faculty of Management and Social Communication

The Jagiellonian University

e-mail: karolina.piasnik@doctoral.uj.edu.pl

\title{
INFORMATION MANAGEMENT MODELS AT THE WEBSITES OF CRACOW ACADEMIC LIBRARIES
}

KEYWORDS: Academic libraries. Websites. Multi-case study.

\begin{abstract}
Thesis/Objective - The article is to identify the models of information management used while managing the websites of academic libraries. Research methods - The multi-case study approach was used to analyze five selected libraries. In addition the author made partly structured interviews and, as a qualitative research method, in-depth interviews. Results/Conclusions - Two dominant models of information management were identified. First was noticed in smaller libraries where only one or two web editors were involved and the processes of information management are running fast, although they are subject to mistake risk. Second was noticed in larger institutions where the website is supervised by a whole team of editors and the content control is on higher level but the whole management process takes much more time.
\end{abstract}

